\title{
Evaluating renal function and defining protein requirements in patients affected by anorexia nervosa: a case report
}

\author{
Onfiani G. ${ }^{1}$, Carubbi F. ${ }^{2}$, Pellegrini E. ${ }^{3}$ \\ 'Operating Unit of Internal and Metabolic Medicine, Azienda Ospedaliero-Universitaria of Modena and University of Modena and Reggio Emilia, \\ Civil Hospital of Baggiovara, Via Giardini 1355, 41126, Modena, Italy \\ 2Operating Unit of Internal and Metabolic Medicine, Azienda Ospedaliero-Universitaria of Modena and University of Modena and Reggio Emilia, \\ Civil Hospital of Baggiovara, Department of Biomedical, Metabolic and Neural Sciences, Via Giardini 1355, 41126, Modena, Italy \\ ${ }^{3}$ Operating Unit of Internal and Metabolic Medicine, Azienda Ospedaliero-Universitaria of Modena, Civil Hospital of Baggiovara, Modena, Italy
}

\section{Keywords}

Anorexia nervosa

Eating disorders

Kidney

Renal function

Creatinine clearence

Protein requirements

\begin{abstract}
Anorexia Nervosa (AN) is associated with high somatic comorbidities. Among them, impaired renal function is frequently overlooked by physicians. Since a high rate of individuals affected by AN may become chronically ill, assessing renal function is crucial to prevent further deterioration of the kidney-related condition. An accurate evaluation of GFR is also critical to prevent drug toxicity and to provide appropriate protein requirements during nutritional rehabilitation. Furthermore, optimizing protein intake is key to a positive protein balance and to promote muscle anabolism. Literature is scarce and no univocal guidelines exists to define how to estimate GFR in those patients. Equations relied on serum creatinine may not be accurate to estimate GFR in AN patients, especially in case of cachexia. We therefore describe the case of a women with a 22 year-history of anorexia nervosa, in which eGFR based on serum creatinine was falsely normal and impaired renal function was revealed by unusual electrolytes disturbances. In conclusion, we think clinicians should consider collecting 24-hour urine and calculate creatinine clearance to correctly assess renal function. Dedicated guidelines are needed to define the optimal daily protein intake in malnourished patients with $\mathrm{AN}$ and CKD during weight gain and weight maintenance phases.
\end{abstract}

\section{Riassunto}

L'anoressia nervosa (AN) si associa a diverse comorbidità mediche. Fra queste, la compromissione della funzionalità renale è spesso sottovalutata o non diagnosticata dai medici. Una corretta valutazione della funzione renale è cruciale non solo per prevenire un ulteriore deterioramento della stessa nel lungo periodo, ma anche per somministrare farmaci nella giusta posologia evitandone la tossicità. Inoltre, una valutazione accurata della velocità di filtrazione glomerulare (GFR), consente di fornire apporti proteici adeguati. L'apporto proteico, infatti, è fondamentale ai fini di promuovere l'anabolismo muscolare e positivizzare il bilancio azotato. Al momento non sono disponibili linee guida dedicate che definiscano come valutare la funzionalità renale nei pazienti affetti da anoressia nervosa, specialmente in caso di grave malnutrizione. Riportiamo l'interessante caso di una paziente affetta da AN da 22 anni, in cui il deterioramento della funzione renale è stato ipotizzato a partire da alterazioni elettrolitiche plasmatiche. A nostro avviso, nella valutazione di pazienti affetti da anoressia nervosa, si dovrebbe sempre considerare un test di conferma della GFR stimata tramite equazioni basate sulla creatinina plasmatica. Infine, si rendono necessarie linee guida univoche che stabiliscano l'apporto proteico ottimale nei pazienti con AN e insufficienza renale cronica durante la fase di incremento ponderale e di mantenimento del peso.

Copyright @ 2020 Giovanna Onfiani. This is an open-access article distributed under the terms of the Creative Commons Attribution License (CC BY). The use, distribution or reproduction in other forums is permitted, provided the original author(s) and the copyright owner(s) are credited and that the original publication in this journal is cited, in accordance with accepted academic practice. No use, distribution or reproduction is permitted which does not comply with these terms.

Giovanna Onfiani (凶) giovanna.onfiani@gmail.com

Received: 10 November 2020; Accepted: 30 November 2020; Published online: 22 December 2020. doi:10.32044/ijedo.2020.08 


\section{Introduction}

Anorexia Nervosa (AN) is a diffuse eating disorder. According to DSM 5 diagnostic criteria, it is characterized by energy intake restriction, intense fear of gaining weight or becoming fat and disturbance in the way in which one's body weight or shape is experienced. Among European women, the prevalence of AN is $<1-4 \%$ [1], whereas the estimate prevalence in men is 10-times lower. This psychiatric condition is associated also with high somatic comorbidities such as cardiovascular, gynaecologic and reproductive, endocrine, gastrointestinal, neurologic and hematologic ones. Among them, impaired renal function is frequently overlooked and understudied by physicians. Since a high rate of individuals affected by AN may become chronically ill, assessing renal function is crucial to prevent further deterioration of the kidney-related condition. Zipfel et al. reported a 5.2\% prevalence of end-stage renal disease after 21 years of AN [2]. An accurate evaluation of GFR is also crucial to prevent drug toxicity and to provide appropriate protein requirements during nutritional rehabilitation and weight maintenance phases. Serum creatinine is a poor indicator of renal function in patients with anorexia nervosa, especially when muscle masses are very reduced and meat intake is low. We describe the interesting case of a women with a 22 year-history of anorexia nervosa, in which eGFR based on serum creatinine was falsely normal and impaired renal function was revealed by unusual electrolytes disturbances.

\section{The case}

F.G is a 41 years-old woman with a 22 -year history of AN. She also reported self-induced vomiting and laxatives abuse. The remaining medical history was unremarkable except for an appendectomy when she was seventeen. At the admission, she weighed $21.5 \mathrm{Kg}$ and her height was $152 \mathrm{~cm}$. Body Mass Index (BMI) was 9.3, denoting a life-threatening condition of extreme malnutrition. Her blood pressure was $70 / 40 \mathrm{mmHg}$ and heart rate was 70 bpm with normal sinus rhythm. She was hairless and showed dry mucous membrane. Her laboratory findings at admission, after hydrosaline solution infusion, during hospital stay and at discharge were reported in Table 1. Of note, serum potassium level before rehydration therapy was low ( $3 \mathrm{mEq} /$ Liter) and the haemolysis of the blood sample collected led with good chance to an overestimation of the value.
At the urinalysis: specific gravity was 1010 and $\mathrm{pH}$ was 8.5. The urine dipstick test was also positive for protein $(50 \mathrm{mg} / \mathrm{dl})$, urobilinogen $(0.20 \mathrm{mg} / \mathrm{dl})$ and haemo globin $0.20 \mathrm{mg} / \mathrm{dl}$. Microscopic examination of the urine sediment revealed red blood cells, white blood cells and hyaline casts. To complete the initial assessment, an abdominal ultrasound was performed, showing a liver to the upper limit of normal. Kidneys were small with multiple small bilateral cysts (Figure 1). The echocardiogram was normal with preserved EF, no valve dysfunction and minimal pericardial effusion was found. DXA measurements were significant for osteoporosis ( $\mathrm{T}$ score at the femoral neck was of -4.3). Enteral nutrition (EN) by nasogastric feeding tube was implemented. We started EN by providing $25 \mathrm{Kcal} / \mathrm{Kg} /$ day and 1 gr protein $/ \mathrm{Kg} /$ day. Electrolytes abnormalities was treated to prevent refeeding syndrome. Over the following days haemoglobin dropped to $6.3 \mathrm{~g} /$ $\mathrm{dl}$, requiring RBC transfusion. Usually, when nutritional rehabilitation starts and patients are fed carbohydrates, glucose causes insulin incretion, which in turn triggers cellular uptake of phosphate along with potassium and magnesium. Consequently, a decrease in serum phosphorous levels is expected. Cells as well start to produce adenosine triphosphate and 2,3-diphosphoglycerate, which further decreases the body's stores of phosphate. Surprisingly, at the next check, plasmatic phosphorus increased to $5.9 \mathrm{mg} /$ $\mathrm{dl}$ and led the medical team to assume an impaired renal function since serum phosphate concentration is primarily determined by kidneys capability to excrete phosphate. Measured creatinine clearance by 24 -hour urine collection

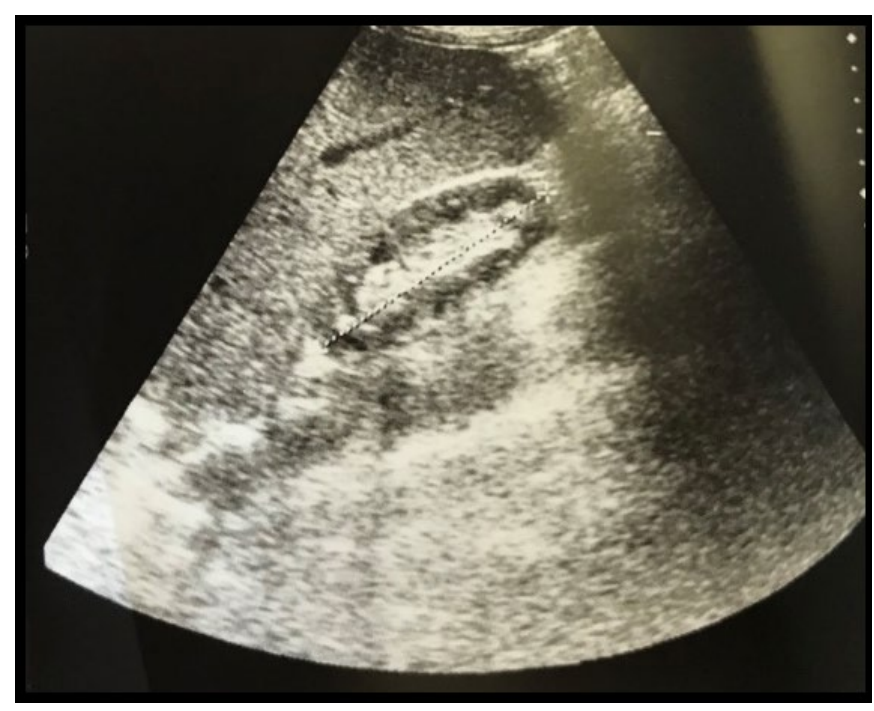

Figure 1. Ultrasound showing a reduced in volume right kidney with multiple small cysts 
Table 1. Laboratory findings at admission, after hydrosaline solution infusion, during hospital stay and at discharge

\begin{tabular}{|c|c|c|c|c|}
\hline Blood test & $\begin{array}{l}\text { At admission } \\
\text { (day 1) }\end{array}$ & $\begin{array}{l}\text { After rehydration } \\
\text { therapy (day 5) }\end{array}$ & $\begin{array}{l}\text { During hospital stay } \\
\text { (day 22) }\end{array}$ & $\begin{array}{l}\text { At discharge } \\
\text { (day 64) }\end{array}$ \\
\hline WBC $\left(\mathrm{n} / \mathrm{mm}^{3}\right)$ & 8.700 & 10.160 & 7.900 & 10.500 \\
\hline $\mathrm{RBC}\left(\mathrm{n} / \mathrm{mm}^{3}\right)$ & 2.950 .000 & 2.270 .000 & 2.830 .000 & 3.460 .00 \\
\hline $\mathrm{Hb}$ (gr/dl) & 7.9 & 6.3 & 8.1 & 10 \\
\hline $\mathrm{Ht}(\%)$ & 24.7 & 19.6 & 25.2 & 31.6 \\
\hline $\operatorname{MCV}(\mathrm{fl})$ & 83.9 & 86.4 & 89.2 & 91.3 \\
\hline Platelets count $\left(\mathrm{n} / \mathrm{mm}^{3}\right)$ & 629.000 & 368.000 & 683.000 & 437.000 \\
\hline Lymphocytes count (n/mm³) & 3.650 & 3.160 & 2.980 & 640 \\
\hline Neutrophils (n/mm3) & 4.460 & 6.400 & 4.270 & 6.300 \\
\hline Glucose (mg/dl) & 84 & 102 & 74 & 83 \\
\hline Urea (mg/dl) & 40 & 18 & 16 & 36 \\
\hline Creatinine (mg/dl) & 1.11 & 0.82 & 0.63 & 0.69 \\
\hline $\begin{array}{l}\text { Renal function assessment } \\
\text { CDK-EPI eq (mil/min) }\end{array}$ & $>60$ & $>60$ & $>60$ & $>60$ \\
\hline $\begin{array}{l}\text { Renal function assessment MDRD } \\
\text { study eq (mil/min) }\end{array}$ & 57.7 & 81.7 & 110.7 & 99.7 \\
\hline $\begin{array}{l}\text { Renal function assessment } \\
\text { Cockcroft-Gault eq (mil/min) }\end{array}$ & 22.6 (weight $21.5 \mathrm{Kg}$ ) & 30.6 (weight $21.5 \mathrm{Kg}$ ) & 49.2 (weight $26.5 \mathrm{Kg}$ ) & 50.8 (weight $30 \mathrm{Kg}$ ) \\
\hline $\begin{array}{l}\text { Creatinine clearance by } 24 \text {-hour } \\
\text { urine collection }\end{array}$ & - & - & 27.4 & - \\
\hline Aspartate aminotransferase (U/L) & 45 & 42 & 34 & 42 \\
\hline Alanine aminotransferase (U/L) & 14 & 11 & 21 & 27 \\
\hline Gamma-gltamyltransferase (U/L) & 86 & 56 & 42 & 23 \\
\hline Alkaline phosphatse (U/L) & 159 & 125 & 129 & 171 \\
\hline Total Protein (gr/dl) & 5 & 4 & - & - \\
\hline Albumin (gr/dl) & 2.6 & 2 & 3 & - \\
\hline Transferrin (mg/dl) & 167 & 124 & 268 & - \\
\hline Ferritin (ng/ml) & 32 & 26 & 13 & - \\
\hline B12 (pg/ml) & - & $>1500$ & - & - \\
\hline Folic Acid (ng/ml) & - & $>22$ & - & - \\
\hline Sodium (mEq/L) & 133 & 135 & 140 & 138 \\
\hline Potassium (mEq/L) & 3 & 4.4 & 4.7 & 4.7 \\
\hline Calcium (mg/dl) & $\begin{array}{l}8.5 \text { ( } 9.6 \text { if corrected for } \\
\text { Hypoalbuminemia) }\end{array}$ & $\begin{array}{l}7.6 \text { ( } 9.2 \text { if corrected for } \\
\text { Hypoalbuminemia) }\end{array}$ & $\begin{array}{l}8.7 \text { ( } 9.5 \text { if corrected for } \\
\text { Hypoalbuminemia) }\end{array}$ & 9.5 \\
\hline Phospohorus (mg/dl) & 4.1 & 5.1 & 5 & 5.2 \\
\hline CRP (mg/dl) & 0.5 & 1.6 & 0.5 & - \\
\hline
\end{tabular}


was $21.4 \mathrm{ml} / \mathrm{min}$, corresponding to a G4 stage according to KDIGO revised classification (2012). Phosphorus infusion was therefore stopped to prevent further kidney injury. A venous blood gas (VBG) was performed with the purpose of assessing ventilation and/or acid-base status, revealing a normal $\mathrm{pH}$. Successive measurements of urinary creatinine were repeated resulting in GFR values between 16.2 $\mathrm{ml} / \mathrm{min}$ and $27.4 \mathrm{ml} / \mathrm{min}$. After consulting, a nephrologist suggested a renal ultrasound with doppler, which ruled out either stenosis or thrombosis of renal arteries. The main autoimmune markers were negative and monoclonal light chains were not found in the urine. Daily medical examination revealed a not significant swelling of the pretibial region bilaterally and abdominal ultrasound was negative for ascites. A minimal pleural effusion persisted at chest radiograph. A hypokalemic nephrophaty was assumed.

During the hospital stay, the infusion rate of enteral nutrition via nasogastric tube was gradually increased and oral nutrition was implemented. Subsequently, the NS tube was removed and F.G. was able to assume the whole caloric requirements through oral nutrition. The patient was discharged from the medical ward after 68 days and she was referred to a posthospitalization treatment. Her weight was $30 \mathrm{Kg}$, corresponding to a BMI of $12.9 . \mathrm{Kg} / \mathrm{m}^{2}$. Weight trend during hospital stay is reported in Figure 2.

\section{Discussion}

The isotopic glomerular filtration rate measurement is one of the gold standards in determining renal function [3] but it is invasive and requires multiple blood sampling. Therefore, measurement of GFR is too complex to be performed in clinical practice. GFR is usually estimated from serum markers such as creatinine and cystatin $\mathrm{C}$. When comparing cystatin C-based GFR estimates to creatinine-based ones, there was no difference in the bias between the equations. Furthermore, precision in determining GFR may be worse with cystatin C-based GFR estimates than creatinine-based estimates. For these reasons equations relied on serum creatinine and measurement of creatinine clearance are acceptable alternatives to the gold standard. The most used equations are the Chronic Kidney Disease Epidemiology Collaboration (CDK-EPI) equation, the Modification of Diet in Renal Disease (MDRD) study equation and the Cockcroft-Gault equation. The CDK-EPI and the MDRD study equations are normalized to body surface area. The CDK-EPI equation is the most accurate in patients with normal o slightly reduced GFR; however, the performance
Weight trend during hospital stay (Kg)

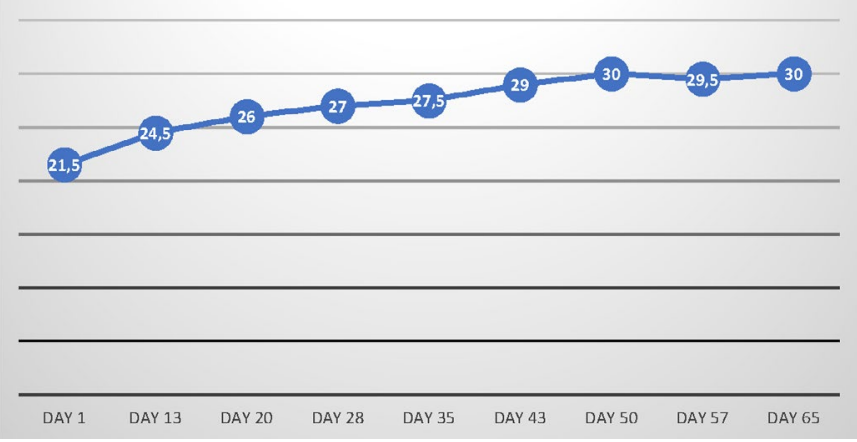

Figure 2. Weight trend during hospital stay

of CDK-EPI and MDRD study equations is similar when lower levels of GFR are considered. The Cockcroft-Gault equation takes into account age and it is the only formula that consider patient's weight in GFR calculation. Equations used to estimate GFR have some limitations due to variations in creatinine production and creatinine secretion, therefore these equations may not be suitable for AN-patients, which have a reduced muscle mass and little or insignificant protein intake. Trahan et al. suggest that Cockcroft-Gault formula is the most reliable tool to estimate renal function in malnourished adolescents with $\mathrm{AN}$; they also demonstrate for the first time that there is no correlation between creatinine levels and isotopic GFR. It is very important to be aware of this lack of correlation to always calculate estimated GFR [4]. Whereas Bouquegneau et al. [5] advocated that MDRD Study equation and Cockcroft-Gault equation substantially overestimate measured GFR. Cystatin C is a low-molecular-weight protein produced by all human nucleated cells and it is freely filtrated by the kidney. Cystatin C is supposed to not be significantly influenced by diet and muscle mass. It seems promising for the evaluation of renal function in $\mathrm{AN}$ patients, by avoiding the influence of undernutrition [6] but only for GFR less than $60 \mathrm{ml} / \mathrm{min} / \mathrm{m}^{2}$. Trahan et al. [4], in their study found no correlation between isotopic glomerular filtration rate measurement and estimation of kidney function based on serum cystatin C. They hypothesized cystatin $\mathrm{C}$ is lowered in undernourished and underweight patients and increases only upon significant renal damage; furthermore, in a context of chronic tubulopathy, cystatin $\mathrm{C}$ can be falsely decreased due to a reduction in the tubular reabsorption of cystatin C.

In 2002, the NKF-KDOQI (National Kidney Foundation's Kidney Disease Outcomes Quality Initiative) guidelines [7] recommend creatinine clearance measurement by 
24-hour urine collection in patients with very abnormal muscular mass, such as those with paraplegia. Since urinary creatinine is partially derived from tubular excretion, the creatinine clearance tends to overestimate the GFR by 10 to 20 percent or more. In addition, errors in urine collection are not infrequent.

According to the most recent KDIGO 2013 guidelines on CKD [8], confirmation of the estimated GFR based on CDK EPI equation is advised in people with factors affecting serum creatinine other than GFR such as low muscle mass or creatinine intake. Confirmatory tests could include estimation upon both cystatin $\mathrm{C}$ and creatinine, or a clearance measurement using either an exogenous filtration marker or a timed urine collection for creatinine clearance.

Therefore, serum creatinine level is a poor-quality indicator of renal function in AN patients. In addition, kidney damage is frequently tubular in its origin and urine sediment examination for haematuria and leukocyturia should be performed in patients with AN and CKD [5]. Literature is scarce and no univocal guidelines exists to define how to estimate GFR in those patients.

In our case, taking into account a serum creatinine of $0.82 \mathrm{mg} / \mathrm{dl}$, according to CDK-EPI and MDRD study equations which are normalized to body surface area, the renal function was falsely normal; while considering the Cockcroft-Gault formula, the estimated GFR was $30.6 \mathrm{ml} /$ $\mathrm{min}$. The 24-hour urine collection confirmed the latter data.

Considering low potassium levels, laxative abuse and vomiting, a hypokalemic nephrophaty was assumed. According to this condition, chronic low potassium levels led to an increase in renal ammonium accumulation in the interstitium. This ammonium would activate complement and therefore damage tubular cells. Concomitant intracellular acidosis stimulates cell proliferation and cyst formation. Growth factors and cytokines production in response to hypokalaemia are also implied [5]. The ultrasound examination revealed small bilateral cyst which are known to be a morphologic aspect of low potassium and low sodium nephropathy [9]. Indeed, increased cortical echogenicity and multiple small bilateral cysts are typically reported in patients affected by hypokalemic nephrophaty [5]. Futhermore, there are some unresolved questions regarding the adequate amount of proteins per body weight to provide during nutritional rehabilitation of patients affected by anorexia nervosa with reduced renal function. The European Society for Clinical Nutrition and Metabolism (ESPEN) guidelines suggest a protein intake of 0.55$0.60 \mathrm{~g} / \mathrm{Kg} /$ die for patients in stage III-V non dialyzed CKD. Loss of protein due to proteinuria exceeding $1 \mathrm{~g} / \mathrm{d}$ should lead to compensatory additions to daily protein intake such as by the calculation of protein/AA intake needed based on ideal body weight ( $\mathrm{kg}$ 0.6-0.8 proteinuria) [10]. While, considering weight loss, extremely low BMI and cachexia, 1.2-1.5 g protein $/ \mathrm{kg} /$ day serves as a target range to maintain or restore lean body mass in malnourished cancer patients; even higher doses of protein may not be useful [11]. However, despite cachexia and marked catabolic state, patients with anorexia nervosa may not have the same degree of inflammation than cancer patients. Rizzoli et al. suggest a dietary protein intake of 1.0-1.2 g/ $\mathrm{kg}$ body weight/d with at least $20-25 \mathrm{~g}$ of high-quality protein at each main meal to maintain musculoskeletal health in postmenopausal women [12]. Finally, The Renal Association recommend a protein intake of $0.8-1.0 \mathrm{~g} / \mathrm{kg}$ ideal body weight (IBW)/day for undernourished patients with stage 4-5 CKD not on dialysis.

\section{Conclusion}

According to KDIGO 2013 guidelines on CKD [8], we think clinicians should consider collecting 24-hour urine and calculate creatinine clearance for each patient admitted to correctly assess renal function. An accurate estimate of GFR is also crucial to avoid further worsening of the kidney function and to define an adequate protein intake. There is not sufficient evidence to routinely recommend low protein diets for people with progressive kidney disease (1C) [13]. We think clinicians should consider providing 0.8-1 g protein $/ \mathrm{Kg} /$ day until optimal weight is reached, if possible and then administer a diet with reduced content of proteins to pursue nephroprotection. Furthermore, dedicated guidelines are needed to clarify optimal protein requirements for patients affected by anorexia nervosa during weight gain and weight maintenance phases. Optimizing protein intake is crucial to support a positive protein balance and to promote muscle anabolism.

\section{References}

1. Keski-Rahkonen and Mustelin (2016) Epidemiology of eating disorders in Europe: prevalence, incidence, comorbidity, course, consequences, and risk factors. Curr Opin Psychiatry 29(6):340-5. https://doi. org/10.1097/yco.0000000000000278

2. Zipfel S, Löwe B, Reas D L, Deter H C, Herzog W (2000) Long-term prognosis in anorexia nervosa: lessons from 
a 21-year follow-up study. Lancet 26;355(9205):721-2. https://doi.org/10.1016/s0140-6736(99)05363-5

3. Disease K: Improving Global Outcomes (KDIGO) CKD-MBD Work Group (2009) KDIGO clinical practice guideline for the diagnosis, evaluation, prevention, and treatment of Chronic Kidney DiseaseMineral and Bone Disorder (CKD-MBD). Kidney Int Suppl (113):S1-130. https://doi.org/10.1038/ ki.2009.188

4. Trahan C, Lapeyraque A-L, Sznajder M, Frappier J-Y, Jamoulle O , Taddeo D , Stheneur C (2020) In malnourished adolescent with anorexia nervosa, Cockcroft-Gault formula is the most relevant formula to estimate renal function. Clin Nutr 39(6):1914-1918. https://doi.org/10.1016/j.clnu.2019.08.014

5. Bouquegneau A, Dubois B E, Krzesinski J-M, Delanaye P (2012) Anorexia Nervosa and the Kidney. Am J Kidney Dis 60(2):299-307. https://doi.org/10.1053/j. ajkd.2012.03.019

6. Delanaye, P., Cavalier, E., Radermecker, R.P., Paquot, N., Depas, G., Chapelle, J.P., Scheen, A.J., Krzesinski, J.M. (2008). Cystatin C or creatinine for detection of stage 3 chronic kidney disease in anorexia nervosa. Nephron Clin Pract 110(3):c158-63. https://doi. org/10.1159/000166607

7. Cano N.J.M., Aparicio M., Brunori G., National Kidney Foundation (2002) K/DOQI clinical practice guideline for chronic kidney disease: evaluation, classification, and stratification. Am J Kidney Dis 39 (2 Suppl 1):S1-266.

8. KDIGO 2012 Clinical Practice Guideline for the Evaluation and Management of Chronic Kidney Disease. Kidney Int Suppl 2013; 3:136.
9. Abdel-Rahman, E.M., Moorthy, A.V. (1997) End-stage renal disease (ESRD) in patients with eating disorders. Clin Nephrol. 47(2):106-11.

10. Cano, N.J.M., Aparicio, M., Brunori, G., Carrero, J.J., Cianciaruso, B., Fiaccadori, E., Lindholm, B., Teplan, V., Fouque, D., Guarnieri, G. (2009) ESPEN Guidelines on Parenteral Nutrition: adult renal failure. Clin Nutr 28(4):401-14. https://doi.org/10.1016/j. clnu.2009.05.016

11. Arends, J., Baracos, V., Bertz, H., Bozzetti, F., Calder, P.C., Deutz, N.E.P., Erickson, N., Laviano, A., Lisanti, M.P., Lobo, D.N., McMillan, D.C., Muscaritoli, M., Ockenga, J., Pirlich, M., Strasser, F., de van der Schueren, M., Van Gossum, A., Vaupel, P., Weimann, A. (2017). ESPEN expert group recommendations for action against cancer-related malnutrition. Clin Nutr 36(5):1187-1196. https://doi.org/10.1016/j.clnu.2017.06.017

12. Rizzoli, R., Stevenson, J.C., Bauer, J.M., van Loon, L.J., Walrand, S., Kanis, J.A., Cooper, C., Brandi, M.L., DiezPerez, A., Reginster, J.Y., ESCEO Task Force (2014). The role of dietary protein and vitamin $\mathrm{D}$ in maintaining musculoskeletal health in postmenopausal women: a consensus statement from the European Society for Clinical and Economic Aspects of Osteoporosis and Osteoarthritis (ESCEO). Maturitas 79(1):122-32. https://doi.org/10.1016/j.maturitas.2014.07.005

13. Wright M, Southcott E, Mac Laughlin H, Wineberg S (2019) Clinical practice guideline on undernutrition in chronic kidney disease. BMC Nephrol 16;20(1):370. https://doi.org/10.1186/s12882-019-1530-8 